\title{
From Workplace to Joblessness: The Determinants of Post-Internship Graduate Unemployment in South Africa
}

\author{
Zethembe Mseleku \\ Faculty of Humanities, \\ University of KwaZulu-Natal, \\ 238 Mazisi Kunene Rd, Glenwood, \\ Durban, 4041, South Africa
}

DOI: https://doi.org/10.36941/ajis-2022-0055

\section{Abstract}

One of the pressing concerns for governments and policy makers across the world is youth unemployment. What is even more devastating is the growing graduate unemployment, particularly in developing countries, and South Africa is no exception. Graduate unemployment in South Africa continues to increase at an alarming rate. Without drastic interventions, this socio-economic problem may sadly double in size in the next decade. Work experience programmes, such as internships, are increasingly supported to address youth unemployment, particularly among graduates. However, the effectiveness of the current interventions to the unemployment problem are questionable. This paper draws from the perspectives of 50 participants to explore the determinants of post-internship graduate unemployment. In particular, this paper adopts the lenses of mismatch theory of unemployment to explain why young people are vulnerable in the labour market irrespective of their education and work experience. The examined perspectives revealed that, beyond limited labour market demand, there is also an increasing "work experience-job mismatch" leading to postinternship graduate unemployment. Due to the number of factors, including the skills mismatch problem, the transition from higher education to full-time employment is difficult for many graduates.

Keywords: Education, Employment, Graduate, Graduate unemployment, Internship

\section{Introduction}

Youth unemployment is a major socio-economic development problem, not only in South Africa, but across the world (International Labour Organization, 2018; Pastore, 2018; Verd, 2019). Accordingly, graduate unemployment has increased overtime and consequently put policy makers, governments, and education institutions under immense pressure (Mohamedbhai, 2015; Pauw et al., 2008; Wu, 2011). Unemployment does not only negatively affect individuals, it also destroys the development prospects of nations. A growing body of research has demonstrated the negative impact of unemployment on various aspects of human life and national development (Ahn et al., 2004; Extremera \& Rey, 2016; Jin et al., 1995; Oluwajodu et al., 2015). For instance, Extremera \& Rey (2016) discovered that lack of life satisfaction and happiness were associated with unemployment and, consequently, the increased suicide risks. It is also evident that unemployment correlates with poor wellbeing, lack of income, lack of access to health care services and low leisure time (Ahn et al., 
2004).

Furthermore, Feather (2012) noted the psychological impact of unemployment on the wellbeing of individuals. In this study, depression and anxiety are common negative outcomes (Feather, 2012). Similarly, the low self-esteem was reported among unemployed individuals (Axelsson \& Ejlertsson, 2002; Shamir, 1986). In the study of socio-economic impact of the unemployment, Mafiri (2005) found that the unemployed individuals suffer income loss and low levels of self-esteem. Unsurprisingly, this study also found social impacts of unemployment which include social unrest and political instability. In many countries, particularly developing countries such as Nigeria, the impact of unemployment on economic growth is evident and it is often associated with inflation and other relevant economic issues (Ademola \& Badiru, 2016; Ajayi et al., 2008). As unemployment literature suggest, graduate unemployment is emerging, yet another pressing development issue that leads to various socio-economic issues. For instance, the correlation between unemployment, poverty, and inequality is evident in South Africa and worldwide (Nattrass, 2002). It is evident that crime, substance abuse, risky sexual behaviour seems to persist in South Africa partially due to the unemployment problem. These issues constitute a major assault on humanity and development in South Africa (Mago, 2014). Therefore, this literature evidence suggests that unemployment is a devastating socio-economic problem which calls for urgent attention.

The number of unemployed people in South Africa was 7.2 million in the last quarter of the year 2020 (Statistics South Africa, 2021). This represents the official unemployment rate of 32,5\% of the working age excluding the discouraged work-seekers (Statistics South Africa, 2021). The Quarterly Labour Force Survey indicates that, of 20,4 million young people aged 15-34 years, about 8,5 million or $41,7 \%$ were not in employment, education or training in the fourth quarter of 2019 (Statistics South Africa, 2020). This statistical evidence indicates that South African youth is the most vulnerable group in the labour market. Similarly, graduate unemployment has continued to rise alongside the overall unemployment rate from 6\% in 1994 to $14 \%$ in 2014 (Statistics South Africa, 2015). It is also very important to indicate that the South African population doubled in size since 1994. The South Africa's mid-year population increased to 59,62 million in 2020 (Statistics South Africa, 2020). Hence, the South African population is predominantly youth, the current most vulnerable group in the labour market. It is, therefore, reasonable that interventions to unemployment are mostly targeted at the youth in South Africa. Among graduates aged 15 to 24 years, the unemployment rate was 31,0\% during the first quarter of 2019 compared to $19,5 \%$ in the 4 th quarter of 2018 , an increase of 11,4 percentage points quarter-on-quarter (Statistics South Africa, 2019). However, graduate unemployment rate is lower than the rate among those with other educational levels. This indicates that education is still the key for youth's access to South African labour market (Statistics South Africa, 2019). While these statistics paint a picture of graduate unemployment in South Africa, using the age category "15-24 years" as used in the labour force survey is misleading as it does not truly reflect the South African youth graduate group. Nevertheless, these statistics are considered in this paper to demonstrate the problem of youth graduate unemployment which continues to increase.

While unemployment is recognised as a major development challenge in South Africa, little has been achieved in addressing this socio-economic issue (Kingdon \& Knight, 2007). As evident in the literature, graduates often struggle to secure employment despite the level of education (Núñez \& Livanos, 2010). Although unemployment has recently been given attention from diverse stakeholders, it has been recognised that graduate unemployment persists. As argued by Asmare \& Mulatie (2014), graduate unemployment, particularly in urban areas, has been a persistent challenge of politicians and policy makers since the 196os. They, however, argued that the issue of unemployment has recently gained attention particularly from government although less has been achieved to address unemployment in general (Asmare \& Mulatie, 2014). Different strategies to address unemployment were implemented by governments and other relevant stakeholders. These strategies include investment in higher education (Wangenge-Ouma, 2010), support for work experience programmes (Bola et al., 2015), and support for entrepreneurship opportunities (Gwija et al., 2014) among others.

Higher education undoubtedly plays a significant role in supporting economic and social 
development of nations (Bloom et al., 2006). At a global level, education, particularly higher education, has been deemed as an engine for sustainable development (Findler et al., 2019; Levchenko et al., 2017; $\mathrm{Wu} \&$ Shen, 2016). In developing countries in particular, higher education is widely accepted as an investment in human capital which often contributes to human development, economic development, and poverty reduction (Bloom et al., 2006). Subsequently, the South African government and other relevant stakeholders have invested in higher education through awarding bursaries, scholarships, and financial aid to deserving students (Harry et al., 2018). Evidently, this investment increased the participation of previously disadvantaged youth in higher education. Research evidence also suggests that higher education improves the employability of youth through knowledge and skills development (Figueiredo et al., 2017; Marks, 2017; Mok, 2016). Unfortunately, the graduate unemployment has accordingly increased alongside the increase in higher education enrolments (Altman, 2003; Baah-Boateng, 2014; Harry et al., 2018). Clearly, education alone is not a drastic solution to graduate unemployment (Brzinsky-Fay, 2017; Tomlinson, 2008).

The concept of unemployment has been given significant attention in the literature. However, there is a need for further context specific inquiry of the factors influencing this phenomenon, particularly factors determining post-internship graduate unemployment. Despite a robust debate on unemployment, a mutual ground on its definition has been established in the literature. The most common definition of unemployment can be extracted from the International Labour Organization (2018), where unemployment is defined as a situation where people of the working age are without work during the reference period; that is, they are not in paid employment or self-employment. These individuals must be currently available for work, available for paid employment or self-employment during the reference period (Brandolini et al., 2006; International Labour Organization, 2018). This paper, however, focuses on 'graduate unemployment' which is defined as a situation where academically qualified individuals are available for work but cannot find employment after graduation (Bee \& Dolton, 1990). It is further indicated that graduate unemployment occurs when people with academic qualifications ranging from diploma, bachelors degree, honours degree, masters degree, and doctoral degree are willing to work and searching for employment but cannot find employment (Bai, 2006).

The purpose of this paper is to explore the factors determining post-internship graduate unemployment. The critical question behind this purpose is why graduates are vulnerable to unemployment despite their level of education and work experience. The interplay between education and employability is questionable in the era of rising graduate unemployment. This challenge actually contradicts studies suggesting that higher education level relates to employability (Oluwajodu et al., 2015). While the causes of graduate unemployment have generally been addressed in the literature (Farah \& Ali, 2018; Gupta et al., 2020; Hoxhaj, 2017; Nnatu \& Ochuko, 2017; Singh, 2018), these studies did not address the determinants of graduate unemployment post-internship. The factors leading to graduate unemployment after internship require investigation that will inform new policies, strategies, and programmes to address unemployment. Therefore, this paper is desired to contribute to the solutions of post-internship graduate unemployment, improve higher education and contribute to the development of graduate internship programmes. It therefore integrates the perspectives of graduate interns, mentors, and HR managers to understand the determinants of graduate unemployment, particularly after internship.

\section{The Mismatch Theory of Unemployment}

This paper adopts the lenses of the mismatch theory of unemployment to explain the factors determining post-internship graduate unemployment. The mismatch theory of unemployment states that people are unemployed because they lack skills for the jobs that are available in the market (Birchenall, 2010). This means the skills possessed by job seekers are not aligned with the skills required by employers for available jobs. Based on the mismatch theory, unemployment is the result of the increasing mismatch as the number of unemployed workers increases and jobs in different 
locations decreases, and the gap between skills availability and skills in demand (Birchenall, 2010; Marinescu \& Rathelot, 2018). Therefore, mismatch occurs when there is the existence of disequilibrium between labour supply with certain skills and demand with certain skills (Obadic, 2006). It is also argued that the notion of mismatch indicates the existing gap between unemployment and vacancies available in the market (Obadic, 2006). In economics, the mismatch theory is also used to explain the disconnection between the supply and demand for labour due to rapid competitiveness of the global market associated with technological advancement (Obadic, 2006). While geography is influential to mismatch unemployment (Covington, 2018), recent studies also reveal that the rapid increase in access to higher education led to the increase in graduate unemployment (Ghaffarzadegan et al., 2017). In this paper, post-internship graduate unemployment is partially explained because of the mismatch between skills possessed by graduates and skills needed by employers. The mismatch theory, for instance, recognizes that the extent of graduate unemployment is highly related to the mismatches between graduates' competences and the requirements of the industry. The evidence for this argument is also highlighted in the literature to some extent and the use of mismatch theory is considered useful to explain the mismatch between skills, knowledge, and job market requirements in relation to graduate unemployment. Very significantly, this study explains the discrepancy between skills provided through the graduate internship programme and the skills in demand by employers. To some degree, the post-internship graduate unemployment is attributed to this type of mismatch in this study. While the graduate internship programmes complement the graduates' skill set from higher education, this study demonstrates that such a skill set may be incompatible with graduates' study fields and needs of employers. Ideally, if graduate unemployment is attributed to skills mismatch, employers should experience the shortage of skilled employees. This study demonstrates that it is not only the skills mismatch problem that results in graduate unemployment.

\section{Irrelevant Skills and Graduate Unemployment}

Scientific research has been conducted on the issue of unemployment, particularly the causes of unemployment. Harry et al. (2018) found that employability is influenced by the combination of factors. These factors include poor socio-economic status, poor education system, curriculum issues, the choice of higher education institution and social connections to which the student belongs to (Harry et al., 2018). In relation to poor education system and curriculum issues, previous studies have identified skills mismatch as one of the factors leading to unemployment (Farooq, 2011; Ghaffarzadegan et al., 2017; Herrera \& Merceron, 2013; Kupets, 2016; Marinescu \& Rathelot, 2018). The study of graduate unemployment in Nigeria, for instance, discovered the gap between universities and employers (Longe, 2017). As a result, the skills required for employability were not provided to Nigerian university graduates which increased graduate unemployment in the country (Longe, 2017). Graduates often lack skills for jobs available and possess skills for jobs unavailable (Wu, 2011). This skills mismatch problem is also evident among graduates who have managed to secure employment. According to Nason (2019), employers identified lack of relevant skills from recently employed graduates. Although lack of skills has a direct impact on work productivity, it is possible that employees can develop even more relevant skills and become better employees on duty. This undesired evidence suggests the pressing need to close the gap between tertiary education institutions and the industry to address graduate unemployment.

\section{Higher Education Expansion and Graduate Unemployment}

In response to the impact of globalization on national development, governments and development agencies invested in higher education as an important aspect of global competitiveness (Akomolafe \& Adegun, 2009). While the investment on higher education is always considered a positive force towards development, the increase in students' enrolment with tertiary education institutions has 
directly led to the increased burden in the labour marketplace (Bama, 2013). The higher education investment, which is normally in a form of expanding higher education and nurture professionals with high levels of innovation and creativity, is often correlated with employability (Mok, 2016). In fact, the premise of expanding higher education enrolments is based on the notion that better education results in a better quality of life for humans (Mok, 2016). It is also believed that higher education would enhance national competitiveness in a globalizing world (Rowe \& Zegwaard, 2017). For instance, in South Korea, Japan, Taiwan and even Hong Kong and China, higher education was expanded through privatized strategies to meet the growing demand for higher education (Mok, 2016). In addition, most commentators and legislators believe that more expansion of higher education is, despite the expense, an investment in the nation's future (Murphy, 1993). However, the outcome of such investment has proved to be unfavourable given the increase in the number of unemployed graduates, particularly in developing countries. While education and training significantly contribute to employability and economic development as evident in the literature, it is very important to note that the oversupply of human capital can be disastrous if unmatched with the labour demand. Graduate unemployment normally presents itself as a negative outcome of unmatched investment on human capital. Under these circumstances, it remains difficult to deduce whether higher education directly leads to employability.

\section{Economic Stagnation}

Despite the evident role of education on social and economic development, graduate unemployment has been on a steady increase over the years in many countries (Al-Ghoul, 2020; Ampong, 2020). Clearly, the nature of graduate unemployment is multidimensional, but the economic strength plays a crucial role on the levels of unemployment. Wu (2011), for instance, argues that the global economic depression is the major contributor to graduate unemployment. Most nations, including the United States, experienced huge job loss due to the 2007-09 recession. The economic recovery from the global recession crises has been a battle particularly for developing countries (Duygan-Bump et al., 2015; Goodman \& Mance, 2011; Schaal, 2012). In challenging times of economic depression, industries and firms are forced to cut down on employment to cope with and recover from the global economic crisis $(\mathrm{Wu}, 2011)$. In such instances, the economy is therefore unable to provide adequate employment opportunities, particularly for new graduates (Burger \& Woolard, 2005; Pissarides, 2013).

Correspondingly, Cairns et al. (2014) studied the impact of the economic crisis on education and unemployment. In their study, they discovered those graduates who used to enjoy high degree of labour market advantage due to their tertiary educational qualifications are currently finding that their skills and credentials are unwanted (Cairns et al., 2014). This evidence indicates that the economic situation of each country, to a larger extent, determines the demand for labour. In the case of Portugal, the gradually increasing graduate unemployment has resulted in students and other concerned societal members losing faith in the local job market and claiming that the current education system is losing its value (Cairns et al., 2014). This evidence demonstrates the jeopardized ambitions and aspirations for a brighter future of tertiary-educated Portuguese youth, a very disturbing situation that is given less attention in terms of research or policy responses (Cairns et al., 2014). It is very important to indicate that, to some extent, education and economy are interdependent. Therefore, graduate unemployment cannot be blamed on either economy or education separately. Instead, the growing graduate unemployment should be a growing concern, not only for the higher education community, but for all relevant stakeholders including private sector entities.

\section{Lack of Work Experience and Graduate Unemployment}

Previous research also demonstrate the relationship between inexperience and graduate unemployment (Balwawz, 2012; Nattrass, 2002; Oluwajodu et al., 2015). In these studies, the lack of 
relevant work experience has been identified as a major disadvantage for new graduates searching for first employment. This problem is particularly common in countries with high levels of unemployment where new graduates must compete with experienced applicants for a few available vacancies (Nattrass, 2002). Accordingly, Pauw et al. (2006) discovered that most South African graduates failed in the recruitment selection phase because they lacked relevant employability skills and work experience. Most of these graduates, according to Pauw et al. (2006), graduated from historically black institutions where they did not develop employability skills or acquire work experience. In the study conducted in Malaysia, Hassan (2018) found that the growing graduate unemployment stems from the lack of adequate training opportunities in most universities, which implies the lack of readiness amongst graduates. Due to the failure of most universities to equip graduates with work experience, the transition to employment is not direct, not smooth, and it is not a short-term process for most graduates (Dakhal, 2018). While this literature indicates the failure of most higher learning institutions to integrate work experience opportunities in the academic curriculum, this literature can be criticised as it seemingly fails to recognise the inability of the industry to provide work experience opportunities to undergraduate students. Therefore, fixing the higher education-labour market relations requires close scrutiny.

\section{Limited Labour Market Demand and Graduate Unemployment}

While one's relevant skills, knowledge and work experience is important to access employment, extant literature indicates that jobs availability is the determining factor (Bhorat, 2004; Green \& Henseke, 2016; Moleke, 2010). According to Gebisa \& Etana (2019), there are numerous factors determining graduate youth unemployment, including work experience and the quality of education. However, lack of employment opportunities itself remains a critical factor leading to unemployment in Ethiopia and other developing countries (Gebisa \& Etana, 2019). The lack of labour demand is not a unique problem for countries like Ethiopia. For instance, the study which unpacked the perceptions of graduate unemployment among both employed and unemployed graduates was conducted in South Africa. Unsurprisingly, this study recognised the constrained job market characterised by low labour-demand. This study further discovered that graduates who lack job market information and lack job search skills are even more vulnerable in the low demand labour market (Mncayi, 2016). It is also very important to note that the unavailability of jobs due to lack of labour demand is not unique to developing countries, although it has proven severe in developing countries. In Portugal, for instance, graduate unemployment is associated with the labour market crisis (Cairns et al., 2014). According to Cairns et al. (2014), the rise in graduate unemployment is the evidence for the collapsing local graduate job market associated with difficult economic conditions.

\section{Methodology / Methods}

The overall objective of this research was to explore the diverse perspectives on the factors determining post-internship unemployment among recently graduated youth. To achieve this objective, an exploratory research approach was adopted. Diverse perspectives were drawn from the sample of 50 participants including graduate interns, mentors, and HR managers at eThekwini Municipality. They were asked to report the factors contributing to unemployment, particularly what hinders graduates' transition from education institutions and internship programme to full-time employment.

Semi-structured interviews were used to generate insights from selected participants based on a purposive or judgmental sampling technique. The first round of interviews was conducted on current graduate interns who are at the final stages of a 2-year internship programme (30), aged 21 to 35 years, in various departments. The second round of interviews was conducted with municipal officials (13), who have been mentors for at least 5 years in the municipality. The third round of interviews was conducted with Municipal Academy representatives (2), who have been mentors for at least 5 years in 
the municipality. The last round of interviews was conducted with human resources staff members, specifically HR managers (5), who were involved in the recruitment processes in the municipality for at least 5 years.

All interviews conducted were audio recorded and transcribed. These interviews were then analysed using a "thematic content analysis approach". Since this research relied on unstructured data, some data analysis was conducted during the process of data collection as also understood by Bless et al. (1995). The NVivo 12 qualitative data analysis software was used to facilitate thematic data analysis. The permission to conduct the study at the eThekwini municipality was requested and received to study the internship programme from the authorities. The study was accordingly approved as ethically sound by the University of KwaZulu-Natal, Humanities and Social Sciences Research Ethics Committee, protocol reference number: HSS/1307/o17D.

\title{
9. There are Limited Jobs in the Labour Market
}

In line with other studies on graduate unemployment or employability, this research found that graduate unemployment is due to a combination of factors. However, this research found lack of employment in the labour market as the main reason for post-internship graduate unemployment as reported by most participants. The country's economic climate was reported as the determining factor for graduate unemployment, particularly from a human resources perspective. For instance, one HR manager expressed the following:

"There are limited jobs in the country, and there are so many graduates that is why they are still unemployed with their qualifications and work experience. Being qualified does not help when there are no or limited jobs, and graduates should understand this even though it is a sad reality. Then, there should be some way to create jobs for people with limited work experience who have just left the tertiary education institutions" (Participant no 44, HR Manager).

Lack of employment in the labour market is associated with the economic stagnation in the country. It is evident in this research that the limited labour market growth and rapid production of graduates constitutes graduate unemployment as expressed by HR Manager:

\begin{abstract}
"Talking in general, there are really few jobs in the South African labour market. As a result, new graduates struggle to find their first jobs. Another thing is that most graduates do not have qualifications and skills that are in demand in the job market, so with what they have, it is not what is needed by the employers. This is a serious problem because there are few graduates with scarce skills in science, technology, engineering, and mathematics where most jobs are available. To address these problems, obviously there is a need for cooperation and commitment from different stakeholders to find solutions" (Participant no 47, HR Manager).
\end{abstract}

Similarly, a representative of the eThekwini Municipal Academy who serves as a mentor to some graduate interns had the corresponding response. She believes that the problem of graduate unemployment is related to the country's wide problem of growing unemployment. When asked as to why a graduate might be unemployable after completing the internship programme, she had the following explanation:

"I believe that the experience they get from this internship should be enough for them to get entry-level jobs. I mean, they get 2 years of experience, which should be enough. However, we know the situation in the country; there are no jobs. Even if they have the relevant work experience, they can still be jobless because there are no jobs. So, the fact that they are in the work experience programme does not necessarily guarantee that they will be employed after they complete the programme because there are limited jobs in the job market. Most of them, I must say, are still unemployed even though they completed the internship programme because the problem of unemployment is a national problem. It is just a sad reality that our interns can spend 2 years on the programme and still be jobless" (Participant 


\section{no 49, Academy Representative).}

Additionally, mentors who directly work with interns confirmed the difficulties for graduate interns to secure employment mainly because of the lack of jobs in the labour market. For instance, Participant no 33 indicated that there is nothing he can recommend for graduates to secure employment immediately. In his explanation, he stated that there is nothing wrong with graduates or the internship programme itself, but the problem is with the growing unemployment due to the lack of jobs in the labour market as presented below:

"There is honestly nothing I can recommend for interns in order to find employment immediately upon completion of the internship, otherwise I would have done that a long time ago. I know the problem; it is not with them or the internship programme, but it is the national problem of unemployment. These graduates are very good and competent for employment, but they cannot get employment because there are no jobs in the marketplace. There are really few graduates who are disappointing; most of them are good, and you can see that the work readiness is there, and they can work anywhere" (Participant no 33, Mentor).

Therefore, as evident from participants' remarks, lack of unemployment in the labour market is a principal reason for a graduate's inability to secure employment despite internship experience and qualifications. The research shows that even with work experience, graduates struggle to secure employment because there are few available jobs in the market. This problem is associated with the economic stagnation in the country. Due to limited labour market growth while the number of graduates grows rapidly, graduate unemployment is likely to grow accordingly.

\section{Unmatched Graduates' Skills}

The research found skills mismatch as the second determinant for post-internship graduate unemployment. Most graduates are unemployable because they lack relevant skills. As evident by HR managers interviewed, most graduates cannot find employment because their skills, knowledge and experience do not meet the requirements of the jobs available in the market. For instance, one HR manager interviewed expressed the following as the reason for graduate unemployment:

"One thing I know for sure as I have been working in a human resources department for years is that graduates do not get employment not because they do not have qualifications, skills, knowledge or even experience, but they do not get employment because what they have is not what is needed by the employers. This is a problem because so much investment is made towards the education of these graduates, including through the work experience programme offered by this municipality but, unfortunately, they cannot be employed because of the irrelevancy of either their qualifications, skills or experience or the combination of all these features" (Participant no 45, HR Manager).

While it is believed that higher education institutions, to some degree, are meant to feed the job market through producing competent graduates with skills and knowledge needed by industry, it was found that employers are concerned with these institutions. All human resource staff members who have been involved in recruitment for at least more than five years expressed that new graduates lack adequate knowledge and skills in their field of studies. Thus, employers believe that, to some degree, it is the failure of higher learning institutions to train graduates that leads to graduate unemployment. The research further discovered that even graduates with experience acquired through work experience programmes are not employable. This is partially due to irrelevant internships; hence, they acquire irrelevant work skills, knowledge and experience which does not meet the needs of the job market. This concern raised a question pertaining the value of internship in graduates and its role to graduate employability as expressed by Participant no 48: 
"You know what worries me the most is that even graduates who completed their internships struggle to secure jobs. Do you know why this happens? It is because these graduates are somehow placed in irrelevant units or given tasks which do not necessarily give them relevant work experience that is required by employers. A graduate may have a 2-year work experience, but if it is from an irrelevant unit or accumulated on valueless tasks, such experience becomes useless to potential employers, thus leaving graduates with no jobs. So, I think graduates should be placed in relevant units and given relevant work so that they develop experience that is needed by employers" (Participant no 48, HR Manager).

This evidence regarding irrelevant work experience generated by graduates through internship was also supported in the expression of many interns interviewed. For instance, Participant no 18 expressed how irrelevant her qualifications were to the work she does:

"I cannot say my qualifications are relevant because what I am doing here is more of an administrative work. I think I should be doing more and getting involved more if I were to find my knowledge and skills from the university relevant and applicable. To be honest, sometimes I feel as if I am a PA or a Secretary to my manager, which is not what I wanted to do with my life. Sometimes I wish I were to be given more meaningful work, I mean, getting involved in projects. The kind of work I do can be done by someone who never went to the university or someone with matric, which means what I am doing does not add up. Mmmmmuuuum, on that one I am not sure because what I am doing here is totally different from what I was doing at the university. I studied IOS, and here I ended up getting involved in things that have to do with the Maritime industry. Well, for administrative activities I think my skills and knowledge from the university are applicable. At the university you get those basic admin skills, including the ability to use computer programmes. You know, things like emailing, printing, photocopying, and the use of the internet" (Participant no 18, Intern).

While there are other common causes of graduate unemployment such as the lack of employment itself in the labour market, skills mismatch is another critical drawback for graduate employment. As evident in this research, irrelevant kills, knowledge, and experience among graduates is the cause of concern for most employers and thus undermines graduate employment. Most worryingly, the work experience accumulated by some graduates through internships or work experience programmes may not meet the needs of employers, thus symbolize the reduced value for internships. This issue is expressed by employers as the lack of work experience among graduates.

\section{Limited or No Work Experience}

This research discovered that the lack of work experience is one of the factors determining graduates' ability to secure unemployment. All five HR Managers interviewed indicated that one of the main causes for a graduate's vulnerability to unemployment is the lack of work experience. In particular, HR participants indicated that most jobs advertised by employers in different fields required at least some level of relevant work experience. Unfortunately, most new graduates do not have the required work experience. For instance, one HR manager reported that the lack of work experience is a major challenge for new graduates as even entry-level jobs require some considerable level of work experience from candidates:

"I think we all know how important work experience is for one to get employment, not just work experience, but I mean relevant work experience. Well, our graduates have good relevant qualifications, but when it comes to work experience, they do not have any, and you cannot blame them for that because it is a national problem. As employers, we cannot employ someone only based on qualifications because we consider work experience as equally important. So, with new graduates, because they do not have the needed work experience, it becomes a problem for them to get jobs" (Participant no 46, HR Manager).

Similarly, another participant from the HR department highlighted that it is highly difficult for graduates to access employment because they do not have work experience. This participant 
indicated that most employers tend to place more emphasis on work experience which fresh graduates do not have. When responding, Participant no 48 reported the following:

"This is not meant to say graduates' qualifications are not important for them to perform their duties, but it is just obvious that without relevant work experience, employers will doubt candidates. So, in as much as qualifications are important, the relevant work experience is also important. This is the reason why new graduates struggle to find jobs; employers need work experience which they do not have" (Participant no 48, HR Manager).

While graduates may possess relevant qualifications, this research discovered that these graduates struggle to find employment because they do not have relevant work experience. All HR staff members reported that one of the main reasons why graduates are unemployable is because they lack relevant work experience.

\section{Discrimination, Favoritism and Nepotism}

Discrimination, favoritism, and nepotism were also discovered as critical factors contributing to graduate unemployment. Some graduates expressed that even though they qualified for specific jobs, they would struggle to find employment because they were discriminated against by employers. Other graduates expressed that employers gave priority to some applicants even if they did not qualify. Also, a substantial number of graduates reported that nepotism is what leads to graduate unemployment. When asked about the causes of graduate unemployment, Participant no 19 expressed the following:

"I think the problem is that some employers will choose to employ other candidates and not you because of your race. For instance, what I have noticed is that in whites-owned firms, if you are black, you have less chances to be employed compared to white applicants no matter how much you qualify. Have you seen white graduates in this internship? No, why? It is simple because they are whites, and they know it will be easy for them to get employment even without work experience. It is not like they leave universities with work experience; it is because of discrimination which favors them. It is very sad that you can have your experience but still not get a job because of your skin color" (Participant no 19, Intern).

The response from Participant no 19 emphasized discrimination against graduates by employers in terms of race, however other graduates expressed discrimination in terms of age. For instance, Participant no 27 indicated that most graduates are disqualified for employment by employers based on their age as indicated below:

"What is disturbing me as I am an intern in this municipality is that we observe everything that is done every day. For example, ever since I joined the municipality, I noticed that most posts are taken by old people, not people in our age category, yet they have interns who are youth. Even for junior posts, like level 5 or 6 posts that you will need a 1-year internship to qualify for, they are taken by old people, and I think they do not believe in us because we are young. Maybe they think we cannot take our work seriously because we are young. I do not know what to say, but that is what I observed here" (Participant no 27 , Intern).

Favoritism was also expressed as another factor contributing to graduate unemployment. Some interns expressed that they observed that in the municipality, interns were denied jobs because some people were given preferential treatment to secure such jobs not based on the level at which they are qualified. When asked about the causes of graduate unemployment, Participant no 2 indicated the following:

"The first challenge is that the experience I am getting through this internship is not enough and that, obviously, there are no jobs. The municipal posts are advertised every 2 weeks, but then, I mean, for 
instance, in my unit (Economic Development), there are so many posts that have been released, but they do not call interns for interviews. I really do not know where they want us to utilize the experience we are getting. Intern is always not an option for decent posts, only in a few cases for lower posts such as principal clerk; this is a serious problem" (Participant no 2, Intern).

Therefore, discrimination, favoritism and nepotism are critical factors that determine the employability of graduates to some degree. This research shows that graduates feel they are discriminated against by employers, either in terms of race or age, hence employers do not consider them for employment. On the other hand, some interns revealed what they observed as the factors leading to their unemployment. Both discrimination, favoritism and nepotism were reported by interns as undermining the potential for graduates to secure their first jobs.

\section{Bad Attitude of Graduates}

The research further discovered that bad attitude among graduates towards employment opportunities is another reason why it is difficult for them to secure employment. The attitude was expressed in terms of being selective of jobs and prioritize their feelings or personal needs over employment. In addition to other factors highlighted in the previous sections, HR staff members also reported that new graduates fail to secure jobs because of the bad attitude and poor work ethic. Similarly, mentors who directly work with interns also indicated that attitude is what draws the line between successful and unsuccessful interns. In this regard, Participant no 48 from the HR department indicated the following:

"Most graduates have a very bad attitude towards employment. Graduates are often selective when it comes to job applications; they do not want the low status and low paying jobs. While they are still unemployed, I think they should just apply for all jobs available in the job market. They may not possess enough experience and hence be disqualified for most jobs, but they must be in a position to take whatever available jobs and then continue searching. These graduates also have this bad tendency of searching for good-paying jobs, and they want to work close to their homes or around the city. This type of attitude reduces their chances of finding employment" (Participant no 48, HR Manager).

Similarly, Participant no 46 indicated that graduates must take any opportunity which comes their way because the economic conditions are not favorable for them to apply for only specific jobs that suit their careers. This participant had the following expression regarding the attitude of graduates:

"I know how it is to be a graduate, and I understand that no one likes to do what they have no interest in. However, they need to understand that their dream jobs are not readily available, and they cannot afford to wait for such jobs to be available unless they create their own, which is not easy. So, what they need to do is to take whatever opportunity that is available to them while chasing their dreams. What I have noticed is that they do not want to apply for low grade jobs or jobs that are not in their fields because they believe they deserve better. That can be true, but they must be willing to start somewhere" (Participant no 46, HR Manager).

On the other hand, mentors were concerned about the way graduates behave in the workplace. Some mentors reported difficulties in working with graduates because of bad attitude. Rather than showing initiative and commitment to add value to the departments, some graduates expect their mentors to chase them to do their work as expressed in the words of Participant no 41:

"The problem that I have encountered in working with graduates in our unit is the bad attitude that they express in the workplace. Some want to be chased, and they do not want to do their work. As mentors, we are not here to babysit people with qualifications who know what is right and what is wrong. This is the main reason why they do not learn anything out of their internships because they are not committed to learning. They know they need work experience and the programme is in place to help them, but they 
behave like they are here to do someone a favor. I honestly believe that having a good attitude towards work can take them far with their careers" (Participant no 41, Mentor).

As shown above, bad attitude among graduates towards employment was highlighted by HR staff and mentors as the critical obstacle for graduates' employability. These results show that graduates are selective as to which employment opportunities they apply for. This means that they might be jobs available to them in the labour market, but they do not apply for such jobs because they are less than what they deserve or irrelevant to their careers. The lack of commitment to learn through an internship was also reported as another drawback for interns to develop skills and experience that would get them their first jobs.

\section{Discussion}

While the factors leading to unemployment have been widely previously studied, this current research addressed factors determining post-internship graduate unemployment. The key finding from this research is that there is a steady increase of post-internship graduate unemployment due to various underlying factors. This research found the lack of jobs in the labour market as the key factor leading to graduates' vulnerability to unemployment post-internship. It is reported in this research and the previous studies (Burger \& Woolard, 2005; Cairns et al., 2014) that the strength of economy determines the labour market opportunities for graduates. This research further notes that the supply and demand of graduates is unmatched under the current economic system. While higher education graduate output has expanded over the years, the labour market growth remains limited. This issue is articulated in the mismatch theory of unemployment which argues that it is the lack of demand which leads to unemployment (Obadic, 2006). The lack of demand for labour in this study is attributed to limited labour market growth, which characterizes poor economies such as in South Africa. Developed countries affected by economic crises, such as the 2007-2009 global crises, may also suffer long-term graduate unemployment (Duygan-Bump et al., 2015). When the number of skilled graduates supplied is higher than the number of skilled graduates demanded by employees in a given economy, the result is graduate unemployment. This problem occurs as graduates equipped with skills through education and practical work experience programmes exceeds the quantity of skilled labour needed in the job market. In a country like South Africa with economy characterized by skills shortages, it is difficult to attribute graduate unemployment to excess supply. However, one can deduce that the post-internship graduate unemployment results from the "skills demand-skills supply" mismatches.

Despite educational qualifications, skills, knowledge and work experience, graduates remain vulnerable to unemployment. In consistent with the previous studies (Farooq, 2011; Ghaffarzadegan et al., 2017; Marinescu \& Rathelot, 2018), this research found skills mismatch as another determinant for post-internship graduate unemployment. This issue occurs when there is a discrepancy between skills possessed by graduates and those required by employers as indicated in the mismatch theory of unemployment (Marinescu \& Rathelot, 2018). Lack of relevant work experience, which is also highlighted in the existing literature (Balwawz, 2012; Oluwajodu et al., 2015), is also found as an obstacle for graduate employment in this research. These research results indicates that while the internship programme provides work exposure and skills to new graduates, the work experience, or even skills gained through internship may either be inadequate or irrelevant. Hence, some graduates are found inexperienced and unemployable post-internship. This problem points to poor planning of internship programmes and inexistence of properly developed monitoring and evaluation systems. As a result, issues such as poor mentorship, incorrect placements and involvement in irrelevant work activities exist and undermine the potential of graduate internship on employability.

Hence, this research discovered that irrespective of work experience acquired through internship, graduates struggle to secure employment. This kind of discrepancy between the work experience of graduates gathered through internship and the work experience needed by employers 
can be termed "work experience-job mismatch". In this situation, graduates are equipped with work experience but remain jobless. Employers will only hire graduates who possess skills they need, while those without the required skills will remain jobless, even with educational qualifications and internship work experience. A policy implication for this problem is that further training, preferable the on-job training, is required for displaced graduates. This research findings also suggest that higher education institutions should develop curricula such that it responds to the needs of the employers. It is also suggested that programmes targeted to empower youth to choose correct careers inline with the needs of the industry should be supported. However, the shortcomings of these proposals is that they overlook the power of human capital demand-supply issues which determines employment opportunities. This fact points towards the policy focus on boosting the economy to enable job creation.

Moreover, the results of this research shows that discrimination, favoritism, and nepotism are other critical factors contributing to graduate unemployment despite qualifications and internship work experience. This research shows that graduates feel they are discriminated against by employers, either in terms of race or age, hence employers do not consider them for employment. While unemployed graduates are generally concerned about these labour market related issues (Asmare \& Mulatie, 2014), these issues were reported devastating to interns. It is likely that these issues would have no major impact on employment if labour demand and supply were matched. Finally, this research attempted to address the attitude of graduates in relation to unemployment. It discovered poor work ethic, lack of job search and being job-choosey as factors undermining graduates' transition from internship to full-time employment. While these issues are found at an individual level, they have a potential impact on work productivity and career prospects of graduates.

\section{Conclusion}

This paper reported the factors influencing post-internship graduate employment as perceived by participants. While lack of employment in the labour market seems like an obvious cause of graduate unemployment, this paper found that the post-internship graduate unemployment is determined by the combination of factors. The lack of employment in the labour market was cited as the main reason for graduate unemployment followed by skills mismatch and lack of work experience. In addition, empirical evidence also shows that discrimination, favouritism, and nepotism undermine graduates' employment prospects despite their capabilities. Also, the paper revealed that bad attitude towards employment is another obstacle for some graduates to access employment. It is therefore recommended that higher education institution-labour market relations should be strengthened. This should involve a cooperative effort on curriculum development that addresses the needs of the industry. Work experience programmes, such as internships, should be integrated in the academic curriculum. Also, policy, mentorship, monitoring, and evaluation systems for work experience programme should be enhanced to avoid the work experience-job mismatch problem discovered in this research. In order to empower youth to choose the correct careers inline with the requirements of the labour market, a community-based career guidance should be strengthened in support from civil society, government, private sector, and academic institutions. While this research addressed its objective, it only focused on one internship programme which might have limited the findings. Therefore, a more comprehensive study across diverse graduate internship programmes is recommended. Further research that is aimed at strengthening higher learning institution-labour market relations is also recommended.

\section{Acknowledgements}

This work is based on the research supported by the National Institute for The Humanities and Social Sciences. 


\section{References}

Ademola, A., \& Badiru, A. (2016). The impact of unemployment and inflation on economic growth in Nigeria (1981-2014). International Journal of Business and Economic Sciences Applied Research, 9(1).

Ahn, N., García, J. R., \& Jimeno, J. F. (2004). The impact of unemployment on individual well-being in the EU. European Network of Economic Policy Research Institutes, Working Paper, 29.

Ajayi, K., Adeniji, I. A., \& Adu, E. O. (2008). Graduate unemployment in Nigeria: A blind spot in the Nation's educational system. In the African Symposium (Vol. 8, No. 2, pp. 77-96).

Akomolafe, C. O., \& Adegun, O. A. (2009). Strategies of managing higher education for youth labour market in Nigeria. International NGO Journal, 4(10), 456-466.

Al-Ghoul, K. A. (2020). The Reasons of Unemployment Related to Academic Qualification and Work Environment from the viewpoint of Students Expected to Graduate from King Saud University. Academia, (20-21), 29-50.

Altman, M. (2003). The state of employment and unemployment in South Africa. State of the nation: South Africa, 2004, 158-183.

Ampong, E. (2020). Graduate Unemployment in Ghana: Challenges and Workable Strategies. Graduate Unemployment in Ghana: Challenges and Workable Strategies, 57(1), 16-16.

Asmare, Y., \& Mulatie, M. (2014). A tale of youth graduates unemployment. Global Journal of Human Social Science (A), $14(4), 46-51$.

Axelsson, L., \& Ejlertsson, G. (2002). Self-reported health, self-esteem and social support among young unemployed people: a population-based study. International Journal of Social Welfare, 11(2), 111-119.

Baah-Boateng, W. (2014). Youth employment challenges in Africa: policy options and agenda for future research. In A paper presented at the plenary of the AERC biannual conference, Lusaka, Zambia (Vol. 30).

Bai, L. (2006). Graduate unemployment: Dilemmas and challenges in China's move to mass higher education. The China Quarterly, 185, 128-144.

Baldry, K. (2016). Graduate unemployment in South Africa: social inequality reproduced. Journal of Education and work, 29(7), 788-812.

Balwanz, D. (2012). Youth Skills development, informal employment and the enabling environment in Kenya: Trends and tensions. Journal of International Cooperation in Education, 15(2), 69-91.

Bama, N. K., \& Ile, I. U. (2013). Evaluating Graduate Employability in the City of Cape Town with Specific Reference to the Environmental Internship Programme. Editorial Board, 105.

Bee, M., \& Dolton, P. (1990). Patterns of change in UK graduate unemployment, 1962-87. Higher education, 2o(1), 25-45.

Bhorat, H. (2004). Labour market challenges in the post-apartheid South Africa. South African Journal of Economics, 72(5), 940-977.

Birchenall, J. A. (2010). A competitive theory of mismatch. mimeo, UCSB.

Bless, C. Higson-Smith, C. \& Sithole, S (1995), social research methods: an African perspective, 5th edition, Juta, Cape Town.

Bloom, D. E., Canning, D., \& Chan, K. (2006). Higher education and economic development in Africa (Vol. 102). Washington, DC: World Bank.

Bola, S., Trollip, E., \& Parkinson, F. (2015). The state of South African internships: A national survey against HPCSA guidelines. SAMJ: South African Medical Journal, 105(7), 535-539.

Brandolini, A., Cipollone, P., \& Viviano, E. (2006). Does the ILO definition capture all unemployment? Journal of the European Economic Association, 4(1), 153-179.

Branson, N., \& Leibbrandt, M. (2013). Educational attainment and labour market outcomes in South Africa, 19942010.

Brzinsky-Fay, C. (2017). The interplay of educational and labour market institutions and links to relative youth unemployment. Journal of European Social Policy, 27(4), 346-359.

Burger, R., \& Woolard, I. (2005). The state of the labour market in South Africa after the first decade of democracy. Journal of vocational education and training, 57(4), 453-476.

Cairns, D., Growiec, K., \& de Almeida Alves, N. (2014). Another 'missing middle'? The marginalised majority of tertiary-educated youth in Portugal during the economic crisis. Journal of Youth Studies, 17(8), 1046-106o.

Dhakal, S., Prikshat, V., Nankervis, A., \& Burgess, J. (Eds.). (2018). The Transition from Graduation to Work: Challenges and Strategies in the Twenty-First Century Asia Pacific and Beyond. Springer.

Duygan-Bump, B., Levkov, A., \& Montoriol-Garriga, J. (2015). Financing constraints and unemployment: Evidence from the Great Recession. Journal of Monetary Economics, 75, 89-105.

Extremera, N., \& Rey, L. (2016). Attenuating the negative impact of unemployment: The interactive effects of perceived emotional intelligence and well-being on suicide risk. PLoS One, 11(9), eo163656. 
Farah, S. A., \& Ali, H. A. (2018). A Study on the Causes of Unemployment among University Graduates in Kenya: A Case of Garissa County, Kenya. European Journal of Social Sciences Studies.

Farooq, S. (2011). Mismatch between education and occupation: A case study of Pakistani graduates. The Pakistan Development Review, 531-552.

Feather, N. T. (2012). The psychological impact of unemployment. Springer Science \& Business Media.

Figueiredo, H., Biscaia, R., Rocha, V., \& Teixeira, P. (2017). Should we start worrying? Mass higher education, skill demand and the increasingly complex landscape of young graduates' employment. Studies in Higher Education, 42(8), 1401-1420.

Findler, F., Schönherr, N., Lozano, R., \& Stacherl, B. (2019). Assessing the impacts of higher education institutions on sustainable development-an analysis of tools and indicators. Sustainability, 11(1), 59.

Gebisa, D. A., \& Etana, N. G. (2019). Determinants of Graduate Youth Unemployment. International Journal of Islamic Business and Economics (IJIBEC), 3(2), 90-103.

Ghaffarzadegan, N., Xue, Y., \& Larson, R. C. (2017). Work-education mismatch: An endogenous theory of professionalization. European journal of operational research, 261(3), 1085-1097.

Goodman, C. J., \& Mance, S. M. (2011). Employment loss and the 2007-o9 recession: An overview. Monthly Lab. Rev., 134, 3.

Green, F., \& Henseke, G. (2016). The changing graduate labour market: analysis using a new indicator of graduate jobs. IZA Journal of Labor Policy, 5(1), 14.

Grieve, R. H. (2017). Involuntary unemployment: a reminder. Real World Economics Review, 81.

Gupta, A. K., Meher, B. K., \& Puntambekar, G. L. (2020) Analysis of Perception of Students on Causes of Unemployment and Underemployment among Educated Mass in India. Journal of Xi'an University of Architecture \& Technology. Volume XII, Issue IV, ISSN No : 1006-7930.

Gwija, S. A., Eresia-Eke, C., \& Iwu, C. G. (2014). Assessing the impact of support structures and initiatives to youth entrepreneurship development in a selected Township in the Western Cape Province of South Africa. Mediterranean Journal of Social Sciences, 5(1), 61.

Harry, T., Chinyamurindi, W. T., \& Mjoli, T. (2018). Perceptions of factors that affect employability amongst a sample of final-year students at a rural South African university. SA Journal of Industrial Psychology, 44(1), 1-10.

Hassan, A. (2018). Internship Framework Guidelines for Malaysian Public Higher Education Institutes. Journal of Science, Technology and Innovation Policy, 4(1).

Herrera, J., \& Merceron, S. (2013). Underemployment and job mismatch in Sub-Saharan Africa. Urban Labor Markets in Sub-Saharan Africa, 83-107.

Hoxhaj, M. (2017). Youth unemployment in Albania, causes and consequences. Euro Economica, 36(o2), 159 -168.

International Labour Organization (2018), Unemployment rate -- ILO modelled estimates, May 2018.

Jin, R. L., Shah, C. P., \& Svoboda, T. J. (1995). The impact of unemployment on health: a review of the evidence. CMAJ: Canadian Medical Association Journal, 153(5), 529.

Kingdon, G., \& Knight, J. (2007). Unemployment in South Africa, 1995-2003: Causes, problems and policies. Journal of African Economies, 16(5), 813-848.

Kupets, O. (2016). Education-job mismatch in Ukraine: Too many people with tertiary education or too many jobs for low-skilled?. Journal of Comparative Economics, 44(1), 125-147.

Levchenko, O., Levchenko, A., Horpynchenko, O., \& Tsarenko, I. (2017). The impact of higher education on national economic and social development: comparative analysis.

Longe, O. (2017). Graduate unemployment in Nigeria: causes, consequences and remediable approaches. American International Journal of Contemporary Research, 7(4), 63-73.

Mafiri, M. I. (2005). Socio-economic impact of unemployment (Doctoral dissertation, University of Pretoria).

Mago, S. (2014). Urban youth unemployment in Africa: Whither socio-economic problems. Mediterranean Journal of Social Sciences, 5(9), 33-33.

Marinescu, I., \& Rathelot, R. (2018). Mismatch unemployment and the geography of job search. American Economic Journal: Macroeconomics, 10(3), 42-70.

Marks, G. N. (2017). University and vocational education, and youth labour market outcomes in Australia. Journal of Education and Work, 3o(8), 868-88o.

Mncayi, P. (2016). An analysis of the perceptions of graduate unemployment among graduates from a South African University.

Mohamedbhai, G. (2015). The challenge of graduate unemployment in Africa. International Higher Education, $80(80), 12$.

Mok, K. H. (2016). Massification of higher education, graduate employment and social mobility in the Greater China region. British Journal of Sociology of Education, 37(1), 51-71. 
Moleke, P. (2010). The graduate labour market. Student retention and graduate destination: Higher education and labour market access and success. Pretoria: Human Sciences Research Council.

Murphy, J. (1993). A degree of waste: the economic benefits of educational expansion. Oxford Review of Education, 19(1), 9-31.

Nason, B. V. (2019). Youth Unemployment among Graduates of Tertiary Institutions in Kenya. Africa Journal of Technical and Vocational Education and Training, 4(1), 84-93.

Nattrass, N. (2002). Unemployment, employment and labour-force participation in Khayelitsha/Mitchell's Plain.

Nnatu, S., \& Ochuko, I. (2017). Causes and Implication of Unemployment in Anambra State A study of Onitsha North Local Government Area. International Journal of Social Sciences, 11(4).

Núñez, I., \& Livanos, I. (2010). Higher education and unemployment in Europe: an analysis of the academic subject and national effects. Higher Education, 59(4), 475-487.

Obadić, A. (2006). Theoretical and empirical framework of measuring mismatch on a labour market. Zbornik radova Ekonomskog fakulteta u Rijeci: časopis za ekonomsku teoriju i praksu, 24(1), 55-80.

Oluwajodu, F., Blaauw, D., Greyling, L. and Kleynhans, E.P. (2015). Graduate unemployment in South Africa: Perspectives from the banking sector. SA Journal of Human Resource Management, 13(1), pp.9-pages.

Pastore, F. (2018). Why is youth unemployment so high and different across countries?. IZA World of Labor.

Pauw, K., Bhorat, H., \& Goga, S. (2006). Graduate unemployment in the context of skills shortages, education and training: Findings from a survey. Retrieved December 07, 2020, from http://papers.ssrn.com/sol3/papers.cfm?abstract_id=961353.

Pauw, K., Oosthuizen, M., \& Van Der Westhuizen, C. (20o8). Graduate Unemployment In The Face Of Skills Shortages: A Labour Market Paradox 1. South African journal of economics, 76(1), 45-57.

Pissarides, C. A. (2013). Unemployment in the great recession. Economica, 80(319), 385-403.

Rowe, A. D., \& Zegwaard, K. E. (2017). Developing graduate employability skills and attributes: Curriculum enhancement through work-integrated learning.

Schaal, E. (2012). Uncertainty, productivity and unemployment in the great recession. Federal Reserve Bank of Minneapolis, mimeo.

Shamir, B. (1986). Self-esteem and the psychological impact of unemployment. Social Psychology Quarterly, 61-72.

Singh, R. (2018). The Cause of Unemployment in Current Market Scenario. Vivechan International Journal of Research, 9(1).

Statistics South Africa, 2015. Quarterly labour force survey 2014 Q4: Statistical Release Po211. www.statssa.gov.za.

Statistics South Africa, 2019. Quarterly labour force survey 2018 Q4: Statistical Release Po211. www.statssa.gov.za.

Statistics South Africa, 2021. Quarterly labour force survey 2020 Q4: Statistical Release Po211. www.statssa.gov.za.

Tomlinson, M. (2008). 'The degree is not enough': students' perceptions of the role of higher education credentials for graduate work and employability. British journal of sociology of education, 29(1), 49-61.

Verd, J. M., Barranco, O., \& Bolíbar, M. (2019). Youth unemployment and employment trajectories in Spain during the Great Recession: what are the determinants?. Journal for Labour Market Research, 53(1), 1-20.

Wangenge-Ouma, G. (2010). Funding and the attainment of transformation goals in South Africa's higher education. Oxford Review of Education, 36(4), 481-497.

$\mathrm{Wu}, \mathrm{C}$. C. (2011). High graduate unemployment rate and Taiwanese undergraduate education. International Journal of Educational Development, 31(3), 303-310.

Wu, C. C. (2011). High graduate unemployment rate and Taiwanese undergraduate education. International Journal of Educational Development, 31(3), 303-310.

Wu, Y. C. J., \& Shen, J. P. (2016). Higher education for sustainable development: a systematic review. International Journal of Sustainability in Higher Education. 